\title{
Inspiring Women in Surgery: Barbara K. Kinder MD, USA
}

\author{
Sanziana Roman ${ }^{1}$
}

Accepted: 11 July 2021 / Published online: 28 August 2021

(C) Société Internationale de Chirurgie 2021

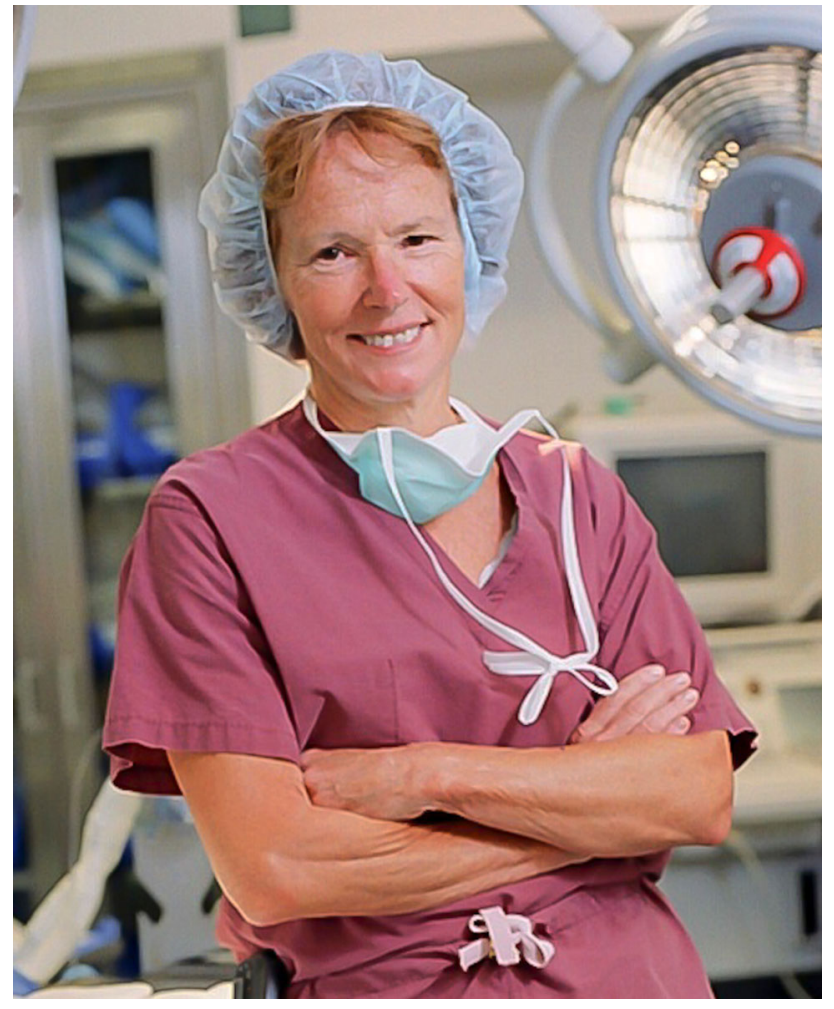

Dr. Barbara Kinder was born in Washington, D.C. in December 1944, when her father was deployed to an aircraft carrier in the South Pacific. She grew up in Cleveland, $\mathrm{OH}$, where her father was a lawyer and her mother, a

Sanziana Roman

Sanziana.roman@ucsf.edu

1 UCSF, 513 Parnassus Ave, San Francisco, CA 94143, USA science enthusiast. Dr Kinder's love for science stemmed from her mother, who had wanted to be a nurse, yet was discouraged by her own physician father, who felt women should not work, and was not pleased when young Barbara gleefully told him she too wanted to be a doctor. She attended Smith College in Massachusetts, where she majored in biochemistry and felt supported in her goal of becoming a physician. In the summers, she worked in a neuroendocrinology laboratory led by Dr. Howard Sachs at Case Western Reserve University, where she completed a study on vasopressin biosynthesis for her Smith College honors thesis. Dr. Sachs was her first real professional mentor, teaching her not only about the scientific process, but awakening her sense of social responsibility. She chose Yale for medical school because its policy of no examinations, but a rigorous thesis requirement, fostered an atmosphere of collegial learning and an opportunity for independent study. She was one of only eight women in a class of 100. Thinking she would specialize in psychiatry, she left her surgical clerkship for the end of her clinical rotations. One day, scrubbed with the chief of plastic surgery, Dr. Tom Krizek, she was inspired by the challenge of removing a large floor of the mouth tumor and reconstructing the oral cavity and face. Asked by Dr Krizek how long she had been interested in surgery, she responded she didn't think it was a good field for a woman. He replied "why?" with honesty. This was a pivotal moment for Barbara, as she realized that there was no good answer indeed. She remained at Yale for surgical residency, one of the first two women (with Mary Alice Helikson, a future pediatric surgeon) to graduate from the pyramidal program. Dr. Kinder remained on faculty at Yale her entire career, where she served as Chief of Surgical Service at the West Haven Veterans Hospital. In collaboration with Fred 
Gorelick and Jim Jamieson in the Yale Department of Cell Biology, she developed a laboratory at the VA which focused on the cell biology of calcium-regulated parathormone secretion. Working with great colleagues, such as Virginia LiVolsi in pathology, and Howard Rasmussen in endocrinology, she focused her clinical practice on the endocrine organs and developed the section of Endocrine Surgery at Yale. She was one of the founding members of the American Association of Endocrine Surgeons and the International Association of Endocrine Surgeons. In 2001, she became the first woman president of the AAES, adding to the many firsts of her career. Dr. Kinder married Dr. Elton Cahow, a renowned hepatopancreatic surgeon at Yale, in 1983, and their daughter, Caitlin, was born in 1985. Caitlin is an extraordinary person, a two-time Olympic ice hockey medalist and an attorney in Chicago. Dr. Cahow died of cancer when Caitlin was only 11 years old. Dr. Kinder later married Joe Adams, an architect, who brought with him his two sons, Garrett and
Christian, who have been brothers-in-arms for Caitlin since the day they met.

Dr. Kinder has mentored and sponsored numerous surgeons along the way; in fact, she may be the model surgeon-scientist and mentor. The AAES honored her legacy by naming one of the major research awards after her just this year. She reflects on her career, noting that "mentors and sponsors make all the difference. We sometimes find them in places we least expect, and in return, we must pay it forward to those who can use our help and encouragement." Mentors often turn into lifelong friends and colleagues. "This is what makes our community of surgeons so wonderful, advancing the art and science of surgery and the care for our patients together."

Publisher's Note Springer Nature remains neutral with regard to jurisdictional claims in published maps and institutional affiliations. 